\title{
Conceptual Design of Maximum Power Point Tracking for Solar Rechargable Airplane
}

\author{
Denis Karabetsky \\ Aviation Computer-Integrated Complexes Department, \\ Educational \& Research Institute of Information and Diagnostic Systems, \\ National Aviation University \\ Kyiv, Ukraine \\ karabetsky@gmail.com
}

\begin{abstract}
This paper shows problem of maximum power point tracking for solar rechargeable airplane; defines problem statement why it is important, structure of the energy system with analysis of each subsystem.
\end{abstract}

Keywords-Solar Rechargable Airplane; unmanned aerial vehicle; maximum power point tracking; Solar cells; Solar power; Battery management;

\section{INTRODUCTION}

When designing solar airplane we should consider idea of weight and energy balances. It means, that life force of aircraft should compensate its weight or must to be equal to it, this is a concept of weight balance. Energy balance means that energy that will be collected through the day should be equal or greater then consumed energy of each airplane part or on-board device [1].

Weight and energy balance and its illustration is on Fig. 1. This figure shows dependencies between weight and energy and parts of airplane that are belong to them.

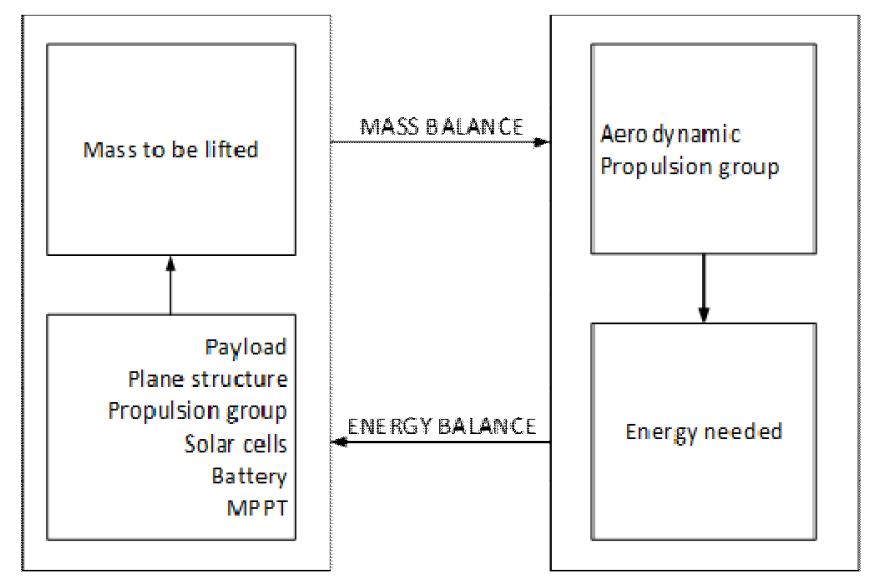

Fig. 1. Energy and mass balance.

At this paper, we will stop on energy balance and factors that affect its efficiency.

Main parts of energy systems are payload (that consumes electric power), solar cells, batteries and charge controller, that handles power line and provides:
- supply power from solar cells for electronics, actuating mechanisms and on-board propulsion system for level flight (day mode);

- collects not used harvested power from solar cells to batteries;

- supply additional power from batteries in case when current power that could be harvested from solar cells is not enough for proper operational needs (night mode).

This solar airplane energy subsystem is shown on Fig. 2.

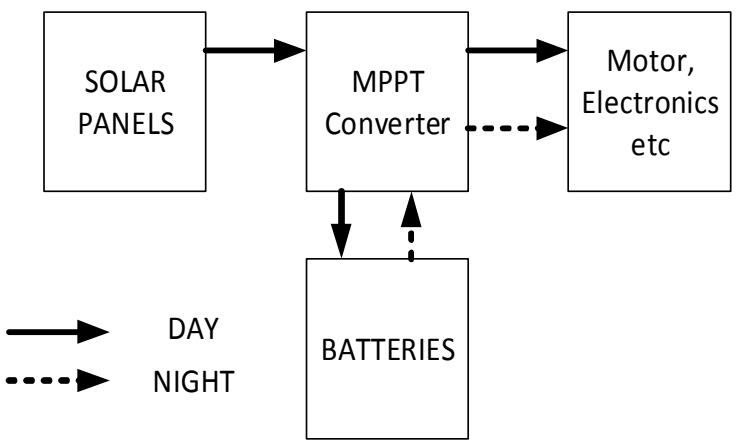

Fig. 2. Solar airplane energy subsystem structure.

Efficiency of power subsystem could be written as:

$$
\eta_{\mathrm{ps}}=\eta_{\mathrm{sc}} \eta_{\mathrm{cc}} \eta_{\mathrm{bat}} \eta_{\text {playload }}
$$

where $\eta_{\mathbf{s}}$ is the efficiency of solar cells; $\eta_{\mathbf{c}}$ is the efficiency of charge controller; $\eta_{\text {bat }}$ is the efficiency of battery module; $\eta_{\text {playload }}$ is the efficiency of payload connected to power line.

Now, we could stop on each part of power subsystem and define critical point and dependencies of its efficiency:

Solar panels. Efficiency of that part could only be improved by few methods: tracking the sun and upgrading solar cell technology.

Charge controller. Efficiency of that part could be improved by tracking characteristics of solar panels and finding power point. 
Batteries module efficiency is quite complex, there are few parts that could be improved: charging efficiency, discharging efficiency and by choosing right battery technology.

This work will stop on discussing charge controller with idea how to use in optimal way solar cells.

\section{Understanding Solar Cells Operation Mode}

For better understanding, how solar cells could work solar cell should be described in terms of equivalent circuit. At literature there are many kinds of models for that circuit we will stop on most popular one - single diode model. It is shown at Fig. 3 [2].

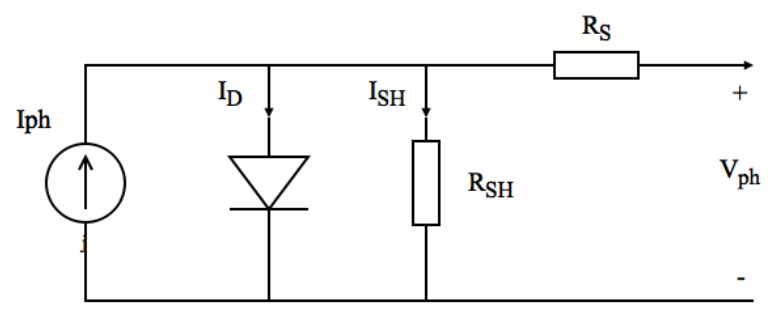

Fig. 3. Solar cell equivalent circuit (single diode model).

where $I$ and $V$ are current and voltage of cell and $I_{L}$ is the cell generated photocurrent, $I_{D}$ is the current of $p-n$ junction, $R_{\mathrm{sh}}$ is the intrinsic shunt and $R_{\mathrm{S}}$ are series resistances of solar cell.

Overall current of solar cell could be represented as:

$$
I_{\mathbf{p v}}=I_{\mathrm{ph}}-I_{\mathrm{rs}}\left(\exp \left(\frac{q V_{\mathrm{pv}}}{k T A}\right)-1\right)
$$

where $q$ is the electron charge; $k$ is the Boltzmann's constant, $A$ is the $p$ - $n$ junction factor constant, $T$ is the cell temperature, $I_{\mathrm{rs}}$ is the reverse saturation current of the cell.

Solar cell is nonlinear device, because equivalent circuit has diode in it and it is based on $p$ - $n$ junction. We should build it characteristics, that could be described by $\mathrm{C}-\mathrm{V}$ and $\mathrm{P}-\mathrm{V}$ curves. Those approximated dependencies are shown at Fig. 4.

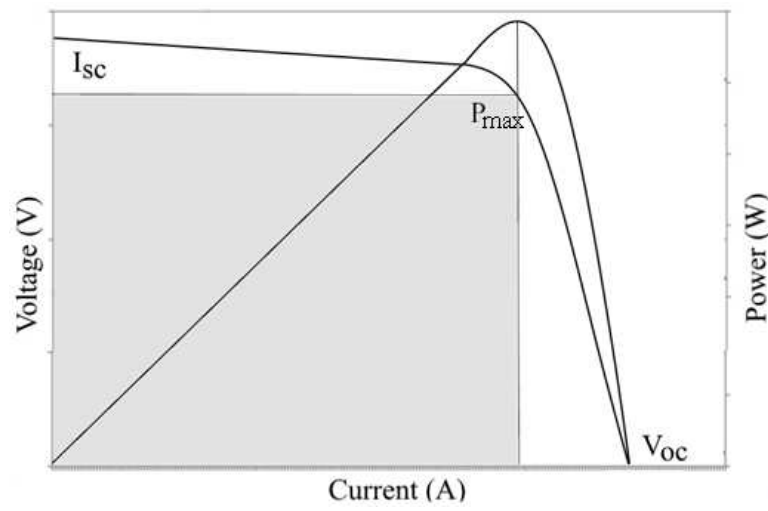

Fig. 4. C-V and P-V curves of solar cells.

P-V curve represents power obtained from the solar cells, and equals zero when it in short circuited state or when there are no current from the panels (open circuit), these points are $I_{\mathrm{sc}}$ and $V_{\mathrm{oc}}$ on the plot. Also, this power curve has a visually maximum point, and maximum power point $\left(P_{\max }\right)$ on $\mathrm{C}-\mathrm{V}$ curve could be reached by:

$$
P_{\max }=I_{\max } V_{\max }
$$

where $I_{\max }$ and $V_{\max }$ could be found on the plot on projection of maximum point of $\mathrm{P}-\mathrm{V}$ curve to $\mathrm{C}-\mathrm{V}$ curve.

On P-V curve that point could be find as maximum by solving:

$$
\frac{d P}{d V}=0
$$

Working near that point is very important, because of power lost. Power loss could be very huge from maximum power when using PWM charging converters or just by randomly selected power point.

But there are many factors that could change $\mathrm{C}-\mathrm{V}$ and $\mathrm{P}-\mathrm{V}$ curves and maximum power point respectively, and they could be divided into two groups:

- temperature changes and irradiance change as environment factors;

- characteristics of payload and internal degradation of solar cells with using bypass diodes - internal factors.

Next, we will look at options that could help find maximum power point in realtime.

\section{MaXimum Power Point Tracking}

Importance of finding optimal power point, where system will work, based on P-V and I-V curves of solar cells that are nonlinear. There are several factors, that was noted before, that could change those characteristics. Also, usage of bypass diodes in strings configuration (as shown at Fig. 5), to avoid partial shading conditions (PSC), could dramatically degrade those characteristics and introduce many local extremums with only one true global maximum power point.

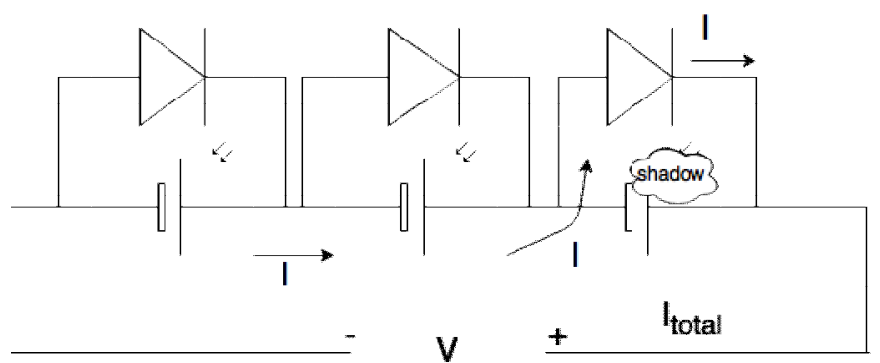

Fig. 5. Solar cell string with bypass diodes to avoid PSO.

In literature exist two groups of tracking algorithms:

Traditional tracking methods - group of methods that could locate maximum power point without guarantee that found point is global maximum. Popular methods: perturb \& observe, incremental conductance, ripple current correlation etc. [3]

Improved traditional tracking methods - group of traditional methods that was improved to use them in PSC applications. 
Global maximum tracking methods - group of methods that was specially developed to find global maximum and be used at application with PSC. Popular implementations of those methods: particle swarm optimization, ant colony, simulation annealing etc.

All those methods could be compared by using several characteristics: (1) tracking time needed to find MPP - less is better because of power loss during tracking; (2) algorithm response time to environment conditions change - less is better because of possible power loss when MPP moving from current power point; (3) steady-state oscillation time - less is better due to possible oscillation near MPP; (4) dependency to specific solar panels - method should be calibrated to specific panels; (5) ability to track global maximum - could be used at PSC applications; (6) complexity and cost of hardware implementation.

TABLE I. POPULAR MPPT ALGORITHMS

\begin{tabular}{|c|c|c|c|c|c|c|}
\hline \multirow{2}{*}{$\begin{array}{l}\text { Alg. } \\
\text { name }\end{array}$} & \multicolumn{4}{|c|}{ Characteristics of methods } & \multirow[b]{2}{*}{ GMPP } & \multirow[b]{2}{*}{$\begin{array}{c}\text { Compe } \\
\text { xity }\end{array}$} \\
\hline & $\begin{array}{c}\text { Trackin } \\
\text { g time }\end{array}$ & $\begin{array}{c}\text { Response } \\
\text { time }\end{array}$ & SSO & $\begin{array}{c}S C \\
\text { specific }\end{array}$ & & \\
\hline $\mathrm{P} \& \mathrm{O}$ & Var & Fast & No & No & No & Low \\
\hline IncCnd & Fast & Fast & No & No & No & Low \\
\hline $\mathrm{RCC}$ & Fast & Fast & No & No & No & Low \\
\hline Fuzzy & Fast & Fast & No & Yes & No & High \\
\hline PSO & Var & Var & No & Yes & Yes & Avg \\
\hline Chaos & Fast & Fast & No & No & Yes & Avg \\
\hline
\end{tabular}

\section{CONCEPTUAl Design OF MPPT Module}

As shown before solar airplane energy subsystem is an important part of solar flight. More detailed structure will be described at this part of the work.

First of all, main purpose of energy subsystem of solar airplane is providing required power to all mandatory modules of aircraft, like power electronics, control electronics and propulsion group. Structure of energy system was shown at Fig. 1, and structure of MPPT module and its connections are shown at Fig. 6.

Mainly MPPT converter are complex device that contains of main parts that could be separated by purpose: MPPT with $\mathrm{dc} / \mathrm{dc}$ converter, battery charger and power line manager.

Idea of MPPT subsystem is increasing efficiency of solar cell usage, as it was discussed at chapter 2 as problematic and at chapter 3 as available base tracking algorithms.

Input of that subsystem is connected to solar cells, when output is providing voltage and current to internal power line at MPP.

Hardware implementation of MPPT converter has several stages: DC/DC converter with PWM control line, it could be SEPIC or buck-boost converter, which used to decrease or increase generated voltage of solar cells; hardware control components (for static control loop) or MCU device with implemented tracking algorithm, that use feedback voltage/current sensors.

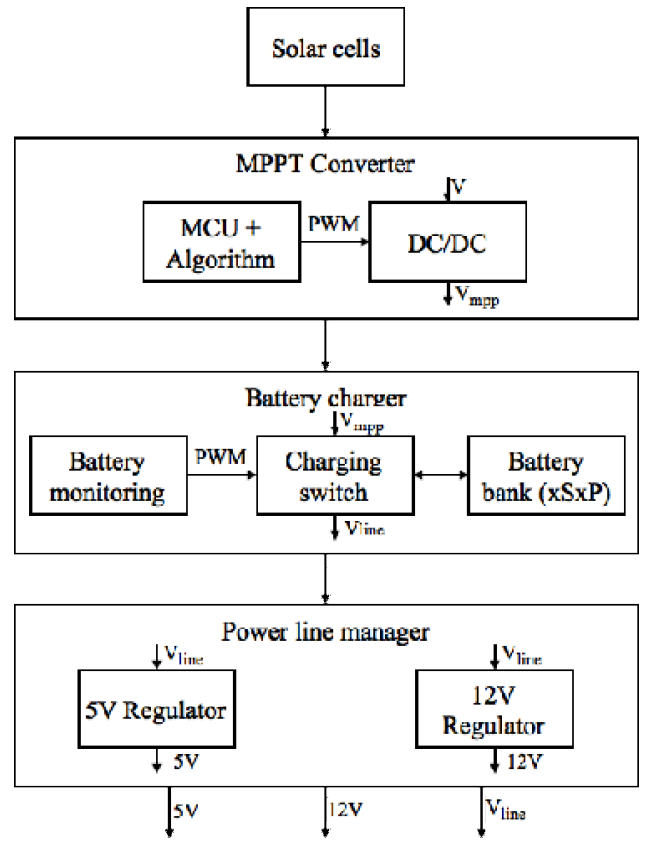

Fig. 6. Structure of MPPT Converter.

Idea of battery charger is quite simple: it should maintain desired level of battery charge level, monitor it and be able to provide energy in case of sun power loss.

Input of that subsystem is connected to internal power line after MPPT converter with power at MPP. Output is stabilized power line for internal components of solar aircraft. Intermediate inputs/outputs connected to battery bank.

Hardware implementation of battery charger also has several stages: battery bank, with different configurations of series and parallel connections; battery monitoring subsystem, that watching battery bank capacity using voltage and current sensors, and could connect bank to power line due to power night/day scenarios.

Idea of power line manager is maintaining required voltage level of power lines, that will be used by propulsion group and control electronics.

Input of that part connected to stabilized power line, when outpus connected to relevant power line derivative (like $5 \mathrm{~V}$, $12 \mathrm{~V}$ etc).

Hardware implementation also quite simple, it contains required $\mathrm{DC} / \mathrm{DC}$ converters that initially configured to fixed output voltage.

\section{REFERENCES}

[1] A. Noth, Design of Solar Powered Airplanes for Continuous Flight, ETH Zurich, 2008.

[2] Vivek Tamrakar, S.C. Gupta and Yashwant Sawle. Single-Diode PV Cell modeling and study of characteristics of single and two-diode equivalent circuit. Electrical and Electronics Engineering: An International Journal (ELELIJ), vol 4, no. 3, August 2015.

[3] M. Muthuramalingam, and P. S. Manoharan, Energy comparative analysis of MPPT techniques for PV system using interleaved softswitching boost converter. World Journal of Modelling and Simulation vol. 11 (2015) no. 2, pp. 83-93. 